\title{
PENGARUH PERPUTARAN KAS DAN PERPUTARAN PERSEDIAAN TERHADAP PROFITABILITAS PERUSAHAAN
}

\author{
Afifah Septiani Judin ${ }^{1}$ \\ Yeni Fitriani Somantri \\ Intan Rahayu ${ }^{3}$ \\ Email: afifahseptiani@gmail.com, ${ }^{1}$ \\ yenifitriani@unper.ac.id.2. \\ intanrahayu@unper.ac.id ${ }^{3}$ \\ Universitas Perjuangan Tasikmalaya ${ }^{1,2,3}$
}

\begin{abstract}
.
The purpose of this research is to know the description of cash turnover, inventory turnover and profitability in cosmetic subsector companies and household needs listed on the Indonesia Stock Exchange for period 2014 to 2019. This study uses quatitative research methods with an assosiative descriptive approach with a causal form of relation-ship. This research uses nonprobability sampling techniques with secondary data types and collection techniques in form of literature research. The data analysis design is used classic assumption test, multiple regression analyses. Based on the result of the study, it is known that the variabel cash turnover partially affects profitability. Partial inventory turnover variables have no effect on profitability, and simultaneously cash turnover and inventory turn-over have a significant impact on profitability. Improving profitability at the company can be done in a variety of ways, including by means, the company can manage its cash turnover as best it can and manage its inventory turnover as wisely as possible. Thus if the company can manage its cash and inventory as best as possible, then the company can get high profitability.
\end{abstract}

\section{Keywords: Cash Turnover, Inventory Turnover and Profitability}

\begin{abstract}
ABSTRAK.
Penelitian ini bertujuan untuk menggambarkan perputaran kas, perputaran persediaan terhadap profitabilitas pada perusahaan subsektor kosmetik dan keperluan rumah tangga yang terdaftar di Bursa Efek Indonesia periode tahun 2014 sampai dengan tahun 2019. Penelitian ini menggunakan metode penelitian kuantitatif dengan pendekatan deskriptif asosiatif dengan bentuk hubungan kausal. Penelitian ini menggunakan teknik sampling Nonprobability Sampling dengan jenis data bersifat sekunder dan teknik pengumpulannya berupa penelitian kepustakaan. Rancangan analisis data yang digunakan menggunakan uji asumsi klasik, analisis regresi berganda. Berdasarkan hasil penelitian, diketahui bahwa variabel perputaran kas secara parsial berpengaruh signifikan terhadap profitabilitas. Variabel perputaran persediaan secara parsial tidak berpengaruh terhadap profitabilitas, dan secara simultan perputaran kas dan perputaran persediaan berpengaruh signifikan terhadap profitabilitas. Meningkatkan profitabilitas pada perusahaan bisa dilakukan dengan berbagai cara, diantaranya dengan cara perusahaan dapat mengelola perputaran kas nya dengan sebaik
\end{abstract}


mungkin dan mengelola perputaran persediannya nya dengan sebijak mungkin. Dengan demikian jika perusahaan dapat melakukan pengelolaan kas dan persediaannya dengan sebaik mungkin, maka perusahaan bisa mendapatkan profitabilitas yang tinggi.

\section{Kata kunci: Perputaran Kas, Perputaran Persediaan, Profitabilitas}

\section{PENDAHULUAN}

Pada era industri saat ini, yang mana semakin berkembangnya dunia usaha maka semakin tinggi pula persaingan yang dihadapi setiap perusahaan untuk bisa mempertahankan kelangsungan usahanya. Ada beberapa hal yang dilakukan perusahaan agar perusahaan tersebut bisa mencapai tujuan yang diinginkannya, yaitu memperoleh keuntungan (Profit), menjaga kelangsungan hidup perusahaan (Going Concern), dan meningkatkan pertumbuhan (Growth). Perputaran kas adalah perbandingan antara penjualan dengan jumlah kas rata-rata (Kasmir : 2016), sedangkan tingkat perputaran kas menunjukkan kecepatan perubahan kembali aset lancar menjadi kas melalui penjualan. Besar kecilnya kas atau perputaran kas yang tinggi maupun rendah dapat memperlihatkan bagaimana perusahaan dapat efisien dalam menggunakan kas pada perusahaannya. Semakin banyak kas pada perusahaan, maka semakin kurang efektif kas yang dimiliki perusahaan. Hal ini juga bisa berdampak pada profitabilitas perusahaan tersebut. Karena semakin tinggi perputaran kas, maka semakin besar kesempatan perusahaan menghasilkan laba. Secara umum persediaan merupakan barang-barang yang dimiliki perusahaan dan barang yang digunakan untuk keperluan perusahaan di masa yang akan datang, persediaan ini meliputi barang produksi dan barang dagang yang dimiliki perusahaan yang nantinya akan didistribusikan dan dijual kembali, dengan demikian persediaan merupakan salah satu komponen perusahaan yang sangat penting, karena jika suatu perusahaan tidak dapat mengelola persediaannya dengan baik, maka akan terjadinya penumpukan persediaan yang mana jika perusahaan terlalu lama menyimpan persediaan maka semakin lambat juga perusahaan mendapatkan laba dari penjualan persediaan tersebut. Industri manufaktur pada sub sektor kosmetik dan keperluan rumah tangga belum mendapat perhatian khusus yang cukup signifikan. Perusahaan kosmetik atau perawatan diri masih menjadi porsi kecil dalam kategori barang konsumsi, terdaftar di bursa saham. Perusahaan yang termasuk dalam sektor ini menyampaikan banyak hal yang mempengaruhi performa emiten selama setahun penuh.

Tabel 1.1

Pertumbuhan Laba Perusahaan Kosmetik dan Keperluan Rumah Tangga (dalam jutaan rupiah)

\begin{tabular}{|l|l|l|}
\hline Tahun & Laba & Pertumbuhan \\
\hline $\mathbf{2 0 1 3}$ & 5.641 .847 .697 & - \\
\hline $\mathbf{2 0 1 4}$ & 6.058 .315 .895 & $7.4 \%$ \\
\hline $\mathbf{2 0 1 5}$ & 6.707 .251 .931 & $10.7 \%$ \\
\hline $\mathbf{2 0 1 6}$ & 6.804 .155 .827 & $1.4 \%$ \\
\hline $\mathbf{2 0 1 7}$ & 7.357 .600 .542 & $8.1 \%$ \\
\hline $\mathbf{2 0 1 8}$ & 9.601 .955 .991 & $30.5 \%$ \\
\hline
\end{tabular}


(Sumber: www.idx.co.id)

Berdasarkan data yang ada pada Tabel 1.1 maka dapat dilihat adanya pertumbuhan laba pada perusahaan sektor kosmetik dan keperluan rumah tangga setiap tahunnya tidak konsisten, yang mana ada tren naik turun dari laba yang di dapatkan setiap perusahaan itu sendiri. Terlihat dalam tabel tersebut pada tahun 2014 perusahaan memiliki kenaikan laba sebesar 7,4\% dari tahun sebelumnya yang mana memiliki nilai sebesar $\mathrm{Rp} 6.058 .315 .895$ dan pada tahun 2015 memiliki kenaikan yang cukup signifikan yaitu sekitar 10,7\% dengan nilai Rp 6.707.251.931 sedangkan pada tahun 2016 memiliki kenaikan yang cukup rendah dibandingkan tahun sebelumnya yaitu hanya 1,4\% dengan nilai Rp 6.804.155.827 tetapi pada tahun 2017 laba pada perusahaan memiliki kenaikan lagi yang cukup tinggi dengan persentase 8,1\% yang memiliki nilai Rp 7.357.600.542 dan pada tahun 2018 perusahaan memiliki kenaikan yang cukup tinggi sekali dengan persentase kenaikan 30,5\% dengan nilai Rp 9.601.955.991 dan untuk tahun 2019 ada penurunan persentasi yang sangat drastis yaitu pertumbuhan laba keseluruhan menurun hingga -14.5\% dengan nilai Rp 8.204.552.415. (Sumber: data diolah dari www.idx.co.id). Perusahaan yang bergerak dalam bidang manufaktur seperti perusahaan industri kosmetik dan keperluan rumah tangga memerlukan perhatian yang lebih terhadap pengelolaan aktiva lancarnya agar lebih efisien, hal ini dikarenakan arus yang stabil untuk pendapatan yang berulang. Selain itu dalam kategori industri ini orang-orang cenderung membeli beberapa produk kosmetik dan keperluan rumah tangga hanya beberapa kali dalam hitungan minggu, sehingga perusahaan jenis ini harus lebih aktif dalam menggunakan aktiva lancarnya.

\section{KAJIAN TEORI}

\section{Perputaran Kas (Cash Turnover)}

Kas merupakan salah satu komponen penting yang harus ada di perusahaan, karena dengan adanya kas aktivitas operasi perusahaan bisa berjalan dengan baik. Entitas harus menjaga jumlah kas tetap stabil agar sesuai dengan kebutuhannya. Jika jumlah kas berkurang, maka kegiatan operasional pun akan terganggu. Tetapi, jika terlalu banyak kas dalam perusahaan, dapat menyebabkan entitas tidak dapat memanfaatkan kas tersebut untuk mendapat imbal hasil yang lebih tinggi. Komponen lain yang terdapat pada kas, yaitu ada laporan arus kas yang melaporkan adanya penerimaan kas, pengeluaran kas dan perubahan bersih kas yang berasal dari aktivitas operasi, investasi dan pendanaan selama periode yang dilaporkan. Laporan arus kas terdiri dari dua macam aliran yaitu: cash in flow yang berarti arus kas yang terjadi dari kegiatan transaksi yang menghasilkan penerimaan kas seperti hasil penjualan produk, penagihan piutang dan lainnya, sedangkan cash out flow yaitu arus kas yang terjadi dari kegiatan transaksi yang mengakibatkan beban pengeluaran kas yang terdiri dari pengeluaran biaya bahan baku, pengeluaran biaya administrasi dan lainnya (Harmono: 2011). Perputaran kas mencerminkan efektivitas modal yang dapat mempengaruhi profitabilitas perusahaan, karena semakin tinggi siklus perputaran kas maka semakin tinggi dan makin efisien juga penggunaan kas perusahaan tersebut, karena dana yang menganggur pada kas akan 
p-ISSN : 2714-8319,e-ISSN: 2714-7452

semakin kecil. Perputaran kas adalah perbandingan antara penjualan dan kas ratarata dan adanya perputaran kas menunjukkan berapa kali kas berputar dalam periode tertentu dalam menghasilkan pendapatan. (Wild, Subramanyam : 2012) perputaran kas dalam satu periode dapat dihitung dengan rumus:

$$
\text { Perputaran Kas }=\frac{\text { Penjualan Bersih }}{\text { Rata }- \text { Rata Kas dan Setara Kas }}
$$

Berarti, semakin tinggi perputaran kas maka semakin cepat kembalinya kas masuk pada perusahaan. Maka dari itu kas akan dapat digunakan kembali untuk membiayai kegiatan operasional perusahaan lainnya. Standar Industri untuk menghitung batasan perputaran kas yaitu sebanyak 50\% dalam satu tahun (Kasmir :2016).

\section{Perputaran Persediaan (Invetory Turnover)}

Perputaran persediaan atau inventory turnover merupakan rasio yang berfungsi untuk mengukur seberapa efisien perusahaan dalam mengendalikan barang dagangan atau persediannya. Indikator dari rasio ini adalah jika semakin besar nilai rasio maka akan semakin efektif pula perusahaan dalam menjual persediaannya tersebut. Menurut Sudana (2015) rasio perputaran persediaan yaitu rasio untuk mengukur perputaran persediaan dalam menghasilkan penjualan dan semakin tinggi rasio berarti menandakan bahwa manajemen perusahaan sudah baik dalam menghasilkan penjualan dan sebaliknya. Kasmir (2016) mengatakan bahwa perputaran persediaan yaitu rasio yang digunakan untuk mengukur berapa kali dana pada perusahaan ditanam dalam persediaan ini berputar dalam satu periode tertentu. Perputaran persediaan dapat pula diartikan sebagai rasio yang menunjukkan berapa kali jumlah barang persediaan diganti dalam satu tahun.

Berdasarkan definisi yang telah dijelaskan sebelumnya, maka dapat disimpulkan bahwa perputaran persediaan adalah cara entitas dalam mengukur berapa kali dana yang tertanam dalam persediaan berputar dalam satu periode, jika semakin tinggi perputaran yang terjadi maka semakin efisien dan efektif pula pengelolaan persediaan yang dilakukan manajemen.

Rumus rasio perputaran persediaan dapat dinyatakan dengan:

$$
\text { Perputaran Persediaan }=\frac{\text { Harga Pokok Penjualan }}{\text { Rata }- \text { Rata Persediaan }}
$$

\section{Profitabilitas}

Setiap perusahaan dalam kegiatan usahanya tentunya memiliki tujuan untuk memperoleh keuntungan atau laba, dalam hal ini manajemen perusahaan dituntut untuk mampu dalam mencapai target perusahaan yang sebelumnya telah direncanakan. Kesuksesan manajemen dalam mengelola keuangan perusahaan tiap periode dapat dilihat dari laba yang dihasilkannya terhadap penjualan dan investasi perusahaan yang dapat dilihat dari unsur laporan keuangan. Karena semakin tinggi nilai rasio maka kondisi perusahaan dinilai semakin baik berdasarkan rasio profitabilitas. Karena hal itu juga nilai rasio yang tinggi melambangkan tingkat laba yang baik dan kinerja perusahaan tinggi yang bisa dilihat dari tingkat pendapatan dan arus kas.Profitabilitas merupakan tujuan akhir yang ingin dicapai 
p-ISSN : 2714-8319,e-ISSN: 2714-7452

suatu perusahaan dan yang terpenting ialah memperoleh laba atau keuntungan yang maksimal, di samping hal-hal lainnya (Kasmir : 2016). Salah satu cara dalam mengukur tingkat keuntungan suatu perusahaan, yaitu digunakan rasio keuntungan atau rasio profitabilitas. Mengukur tingkat profitabilitas merupakan hal yang penting bagi perusahaan, karena profitabilitas yang tinggi merupakan tujuan setiap perusahaan. Sedangkan Munawir (2015) menyatakan bahwa profitabilitas merupakan salah satu pengukuran bagi kinerja suatu perusahaan, profitabilitas suatu perusahaan menunjukkan kemampuan suatu perusahaan dalam menghasilkan laba selama periode tertentu pada tingkat penjualan, aset dan modal saham tertentu. Profitabilitas atau tingkat kemampuan perusahaan dalam memperoleh laba adalah suatu ukuran dalam persentase yang digunakan untuk menilai sejauh mana perusahaan mampu menghasilkan laba pada tingkat yang dapat diterima.

\section{METODE PENELITIAN}

Alat analisis pada penelitian ini menggunakan Analisis Regresi Berganda. Objek dari penelitian ini ada-lah Perputaran Kas, Perputaran Persediaan dan Profitabilitas. Subjek dari penelitian yang dilakukan oleh penulis ini adalah perusahaan manufakur pada sub sektor kosmetik dan keperluan rumah tangga yang ada di Bursa Efek Indonesia tahun 2014 sampai dengan tahun 2019, dengan pengumpulan data sekunder melalui laman web Bursa Efek Indonesia (www.idx.co.id). Populasi dari penelitian ini adalah Perusahaan Manufaktur Subsektor Kosmetik dan Keperluan Rumah Tangga yang Terdaftar di Bursa Efek Indonesia periode tahun 2014 sampai dengan tahun 2019 yang berjumlah 7 perusahaan.

Tabel 3.1

Populasi dan Sampel Penelitian

\begin{tabular}{|l|l|l|}
\hline No & Kode & \multicolumn{1}{|c|}{ Nama Entitas } \\
\hline$(1)$ & $(2)$ & $(3)$ \\
\hline 1 & ADES & Akasha Wira International Tbk \\
\hline 2 & MBTO & Martina Berto Indonesia Tbk \\
\hline 3 & MRAT & Mustika Ratu Indonesia Tbk \\
\hline 4 & KINO & Kino Indonesia Tbk \\
\hline 5 & TCID & Mandom Indonesia Tbk \\
\hline 6 & UNVR & Unilever Indoneisa Tbk \\
\hline
\end{tabular}

(Sumber: www.idx.co.id)

\section{HASIL DAN PEMBAHASAN}

Pengaruh Perputaran Kas Terhadap Profitabilitas

Berdasarkan hasil pengujian secara parsial pada variabel perputaran kas (X1) terhadap profitabilitas maka diperoleh nilai signifikansi $0.000<0.05$ yang mana 
p-ISSN : 2714-8319,e-ISSN: 2714-7452

nilai tersebut memberi simpulan bahwa per-putaran kas berpengaruh secara parsial terhadap profitabilitas. Koefisien korelasi 0.820 bernilai positif dengan memiliki nilai sumbangan efektif (SE) sebesar 64.37\% dan sumbangan relatif (SR) sebesar 95.65\%. Maka dari itu kesimpulan pengujian tersebut adalah bahwa perputaran kas secara parsial ber-pengaruh signifikan terhadap profitabilitas. Adanya pengaruh yang mengindikasi bahwa naik turunnya perputaran kas dapat memprediksi dan menjelaskan naik turunnya profitabilitas, hal tersebut terjadi karena pengaruh dari perputaran kas terhadap profitabilitas perusahaan yang dapat dilihat dari tingkat perputaran yang berkaitan dengan periode dalam pengumpulan kas. Maka semakin cepat periode pen-gumpulan kas berarti mengindikasi semakin tinggi nya tingkat perputaran kas dan semakin cepat pula perusahaan mendapatkan profit dari hasil perputaran kas tersebut.

\section{Pengaruh Perputaran Persediaan Terhadap Profitabilitas}

Hasil pengujian perputaran persediaan terhadap profitabilitas (X2) diperoleh nilai signifikansi sebesar $0.802>0.05$ yang mana hasil tersebut mengindikasi bahwa perputaran persediaan tidak berpengaruh terhadap profitabilitas. Koefisien korelasi 0.628 yang bernilai positif dengan sumbangan efektif (SE) sebe-sar $2.9 \%$ dan sumbangan relative (SR) sebesar 4.35\%. Maka dari itu kesimpulan tersebut adalah bahwa perputaran persediaan secara parsial tidak berpengaruh signifikan terhadap profitabilitas. Hal tersebut menunjukkan bahwa persediaan tidak dapat dijadikan bahan pertimbangan yang mempengaruhi pro-fitabilitas.

\section{Pengaruh Perputaran Kas dan Perputaran Persediaan Secara Simultan Terhadap Profitabilitas}

Menurut pengujian secara simultan atau pengujian menggunakan uji $f$ variabel perputaran kas dan per-putaran persediaan terhadap profitabilitas dalam penelitian ini maka didapat nilai signifikansi sebesar $0.000<0.05$ yang mana hasil tersebut memiliki kesimpulan bahwa perputaran kas dan perputaran per-sediaan berpengaruh signifikan secara simultan terhadap profitabilitas. Hal tersebut berarti jika perputa-ran kas dan perputaran persediaan bergerak secara simultan atau bersama-sama, maka akan memberi-kan pengaruh yang signifikan terhadap profitabilitas. Maka dari itu jika perusahaan dapat mengelola kas dan persediaan dengan lebih baik lagi, kemungkinan profitabilitas yang di dapatkan perusahaan akan terus mengalami peningkatan.

\section{SIMPULAN}

Berdasarkan hasil olah data dari penelitian dan pembahasan mengenai pengaruh perputaran kas dan perputaran persediaan terhadap profitabilitas pada perusahaan kosmetik dan keperluan rumah tangga yang terdaftar pada Bursa Efek Indonesia (BEI) pada periode tahun 2014 sampai dengan tahun 2019, maka kesimpulan yang dapat diambil yaitu sebagai berikut:

1. Perputaran kas secara parsial memiliki pengaruh terhadap profitabilitas pada perusahaan kosmetik dan keperluan rumah tangga yang terdaftar di Bursa Efek Indonesia pada periode tahun 2014 sampai dengan tahun 2019

2. Perputaran persediaan secara parsial tidak memiliki pengaruh terhadap profitabilitas pada perusahaan kosmetik dan keperluan rumah tangga yang 
terdaftar di Bursa Efek Indonesia pada periode tahun 2014 sampai dengan tahun 2019

3. Perputaran kas dan perputaran persediaan secara simultan memiliki pengaruh terhadap profita-bilitas pada perusahaan kosmetik dan keperluan rumah tangga yang terdaftar di Bursa Efek In-donesia pada periode tahun 2014 sampai dengan tahun 2019.

Adapun saran bagi Perusahaan Kosmetik dan Keperluan Rumah Tangga sebaiknya dapat lebih baik dalam mengelola tingkat perputaran kas, perputaran persediaan dan profitabilitasnya, sehingga setiap perusahaan akan mampu bertahan dan bersaing dalam era yang lebih canggih lagi kedepannya, teru-tama pada tahun-tahun berikutnya harus lebih meningkat karena dilihat dari konsumsi masyarakat terhadap kosmetik terutamanya cenderung meningkat dari tahun ke tahun

\section{DAFTAR RUJUKAN}

Bursa Efek Indonesia. (2014, 2015, 2016, 2017, 2018, 2019). Laporan Keuangan Tahunan. Retrieved from www.idx.co.id: htpps://idx.co.id/perusahaantercatat/laporan-keuangan-dan-tahunan/

Ghozali, I. (2017). Aplikasi Analisis Multivariate Dengan Program IBM SPSS. Semarang: Badan Penerbit Universitas Diponegoro.

Harmono. (2011). Manajemen Keuangan Berbasis Balance Scorecard. Jakarta: Bumi Aksara.

Kasmir. (2016). Analisis Laporan Keuangan Cetakan Kesembilan. Jakarta: Rajawali Persada.

Munawir, S. (2015). Analisis Laporan Keuangan. Jakarta: Salemba Empat.

Subramanyam, K. R; Wild, John J; (2012). Analisis Laporan Keuangan. Jakarta: Salmeba Empat.

Sudana, I. M. (2015). Manajemen Keuangan Perusahaan Teori dan Praktik Edisi 2. Jakarta: Erlangga.

Sugiyono. (2018). Metode Penelitian Kuantitatif, Kualitatif, dan R\&D. Bandung: Alfabeta.

www.idx.co.id 